\begin{tabular}{l|l} 
Votaice & e-ISSN: 2655-9404 \\
Vol. 2 No. 3, Oktober 2019 & DOI: 10.20473/ntr.v2i3.16237 \\
\hline
\end{tabular}

Article history: Submitted 4 September 2019 ; Accepted 17 September 2019; Available online 1 October 2019.

\title{
Tanggung Jawab Kurator terhadap Hak Pekerja
}

\author{
Anis Nur Nadhiroh \\ anis.nadhiroh25@gmail.com \\ Universitas Islam Indonesia
}

\begin{abstract}
Related to employment, of course, leaves many questions, in addition to being imagined by the fate of its workers, companies in the business world more often repair the collapse or use bankruptcy. This study aims to understand the position of the Worker or Worker in making decisions on the distribution of bankruptcy proceedings by the Curator. The curator has a big responsibility in distributing bankruptcy assets. Prefer bankruptcy distributed to workers or laborers as Preferent creditors. As a creditor Preferably, that is, the preferred creditor, which has been received by workers or laborers who obtain bankrupt property, is preferred. Bankrupt bounce. The results of the bankruptcy loan. It becomes a separate PR even though it has been regulated in Article 95 Paragraph (4) of the Manpower Act. The method used in this research is normative juridical. Where the intention is to conduct an assessment of the applicable laws and regulations. Inclusive law exists in response to questions that often cannot be answered by law or positive law. As a legal tool to cut off areas that rarely get the attention of law enforcement.
\end{abstract}

Keywords: Bankruptcy; Preferred Creditors; Workers.

\begin{abstract}
Abstrak
Berbicara mengenai ketenagakerjaan tentu menyisakan banyak pertanyaan, selain terbayang oleh nasib para pekerjanya, perusahaan dalam dunia usaha banyak sekali yang mengalami kolaps atau mengalami kepailitan. Penelitian ini bertujuan untuk mengetahui posisi Pekerja atau Buruh dalam pengambilan putusan atas pembagian pada boedel pailit oleh Kurator. Kurator memiliki tanggungjawab besar dalam melakukan pembagian harta hasil pailit. Termasuk harta pailit yang seharusnya dibagikan kepada para pekerja atau buruh sebagai kreditor Preferen. Sebagai kreditor Preferen, yakni kreditor yang diutamakan, sudah seharusnya Pekerja atau buruh dalam memperoleh harta pailit adalah diutamakan. Namun kenyataannya pekerja atau buruh dalam perusahaan yang pailit sering kali tidak memperoleh bagian akan hak-haknya hasil dari boedel pailit. Hal ini menjadi PR tersendiri padahal sudah diatur dalam Pasal 95 Ayat (4) UU Ketenagakerjaan. Adapun metode yang digunakan dalam penelitian ini adalah normative yuridis. Dimana maksudnya adalah dengan melakukan pengkajian terhadap aturan perundang-undangan sebagaimana asas-asas yang berlaku. Hukum inklusif hadir sebagai jawaban atas permasalahan-permasalahan yang kerap kali tidak mampu dijawab oleh undang-undang atau hukum positif. Sebagai sarana hukum untuk menyentuh wilayah yang jarang sekali memperoleh perhatian oleh para penegak hukum.
\end{abstract}

Kata Kunci: Kepailitan; Kreditor Preferen; Pekerja.

\section{Pendahuluan}

Berbicara mengenai ketenagakerjaan tentu menyisakan banyak pertanyaan, selain terbayang oleh nasib para pekerjanya, perusahaan dalam dunia usaha banyak sekali yang mengalami kolaps atau mengalami kepailitan. Hal ini bisa terjadi karena banyak factor, bisa karena manajemen utama dalam perusahaan tersebut 
kurang memadai, bisa juga karena produk yang dihasilkan dari perusahaan tersebut kurang memenuhi kebutuhan pasar. Sehingga dengan keadaan tersebut, lambat laun perusahaan yang awalnya menjadi sumber pemenuhan kebutuhan pasar, ternyata menjadi pailit karena kalah atas persangain pasar itu sendiri.

Mengenai kepailitan, banyak ilmuwan yang berbicara mengenai disiplin ilmu tersebut, di antaranya Djohansah yang memandang Kepailitan merupakan suatu proses dimana seorang debitor yang mempunyai kesulitan keuangan untuk membayar utangnya dinyatakan pailit oleh pengadilan, dalam hal ini adalah Pengadilan Niaga, dikarenakan debitor tersebut tidak dapat membayar utangnya. ${ }^{1}$

Selain Kepailitan merupakan suatu jalan keluar yang bersifat komersial untuk keluar dari persoalan utang piutang yang menghimpit seorang debitor, dimana debitor tersebut sudah tidak mempunyai kemampuan lagi untuk membayar utangutang tersebut kepada para kreditornya. ${ }^{2}$

Bukan hanya itu, Fred B.G. Tumbuan juga mengartikan bahwa Kepailitan adalah sita umum yang mencakup seluruh kekayaan debitor untuk kepentingan semua kreditornya. Tujuan kepailitan adalah pembagian kekayaan debitor oleh kurator kepada semua kreditor dengan memperhatikan hak-hak mereka masing-masing. ${ }^{3}$

Sementara itu dalam Pasal 1 angka (1) Undnag-Undang Nomor 37 tahun 2004 tentang Kepailitan dan Penundaan Kewajiban Pembayaran Utang, yang dimaksud dengan kepailitan adalah sita umum atas semua kekayaan debitor pailit yang pengurusan dan pemberesannya dilakukan oleh Kurator di bawah pengawasan Hakim Pengawas sebagaimana diatur dalam Undang-Undang ini. ${ }^{4}$

\footnotetext{
1 Rudy Lontoh(Ed), Penyelesaian Utang Melalui Pailit Atau Penundaan Kewajiban Pembayaran Utang (Alumni 2001).

2 Dhian Septiandani dan Efy Yulistyowati Dewi Tuti Muryati, 'Pengaturan Tanggung Jawab Kurator Terhadap Pengurusan Dan Pemberesan Harta Pailit Dalam Kaitannya Dengan Hak Kreditor Separatis’ (2017) 19 Jurnal Dinamika Sosial Budaya.[12].

3 Fred B.G. Tumbuan, "Pokok-Pokok Undang-Undang Tentang Kepailitan Sebagaimana Diubah Oleh PERPU No. 1/1998” Dalam Penyelesaian Utang-Piutang Melali Kepailitan Atau Penundaan Kewajiban Pembayaran Utang (Rudhy A. Lontoh ed, Alumni 2001).[125].

4 Imran Nating, Peran dan Tanggung Jawab Kurator dalam Pengurusan dan Pemberesan Harta Pailit, (Jakarta: Rajawali Pers, 2005).[3].
} 
Pernyataan pailit mengakibatkan debitor demi hukum kehilangan hak untuk menguasai dan mengurus kekayaannya yang dimasukkan dalam kepailitan, terhitung sejak pernyataan kepailitan. ${ }^{5}$

Fred B.G. Tumbuan juga menambahkan bahwa melalui sita umum maka dihindari dan diakhiri sita dan eksekusi oleh para kreditor secara sendiri-sendiri. ${ }^{6}$ Dengan demikian para kreditor harus bertindak secara bersama-sama (concursus creditorium) sesuai dengan asas sebagaimana ditetapkan dalam Pasal 1132 KUH Perdata.

Kepailitan dinyatakan oleh hakim dalam pengadilan Niaga. Jika perusahaan sudah dinyatakan pailit, maka boedel kepailitan berupa asset perusahaan akan menjadi harta sitaan yang akan dilakukan pembagian kepada para kreditor yang dilakukan oleh Kurator.

Kurator sendiri dalam melakukan pembagian harta hasil kepailitan pun juga perlu memperhatikan tingkatan para kreditor yang berhak menerima hasil pembagian pertama kali dari hasil kepailitan. Sebab, banyak sekali kasus di lapangan harta daripada debitor yang mengalami kepailitan tidak mencukupi untuk melakukan pembayaran utang kepada para kreditor.

Kreditor dalam menerima harta Pailit diurutkan menjadi Kreditor Separatis, Kreditor Konkuren dan Kreditor Preferen. Dalam pembagiannya Kreditor Separatis didahulukan daripada Kreditor Konkuren dan Kreditor Preferen, sedangkan sejauh ini Buruh berada dalam posisi Kreditor Preferen. Sehingga dalam pembagiannya pun buruh dinomor sekiankan setelah pembagian pada para kreditor Separatis dinyatakan selesai, sedangkan yang termasuk Kreditor Separatis adalah utang perusahaan pada negara, pihak asuransi, fidusia dan lain sebagainya.

Jika penerapannya demikian, maka sejauh ini praktek pembagian harta pailit oleh curator telah melanggar hak para pekerja yang telah diatur secara implisit dalam UU Nomor 13 tahun 2003 tentang Ketenagakerjaan. ${ }^{7}$ Dimana dalam UU terrsebut menyetakan bahwa "maka upah dan hak-hak lainnya dari pekerja/buruh

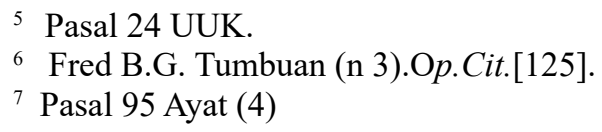


merupakan utang yang didahulukan pembayarannya".

Hal ini bisa terjadi karena, pemaknaan dalam Pasal 95 ayat (4) tersebut meluas, karena tidak dijelaskan secara eksplisit dalam penjelasan makna didahulukan dalam pasal tersebut. Oleh karenanya kondisi tersebut, rawan sekali bagi buruh mengalami ketidak adilan karena dalam posisi ketenaga kerjaan posisi buruh adalah posisi yang begitu lemah untuk memperoleh akses untuk melakukan perubahan.

Oleh karena, karena Pasal tersebut dirasa begitu luas pemaknaannya, maka pemerintah telah mengeluarkan kebijakan baru berupa Putusan MK Nomor 67 tahun 2013 sebagai bentuk upaya mempertegas makna "yang didahuukan" sebagai upaya untuk memperoleh tujuan hukum yakni berupa Kepastian Hukum.

Realitanya pekerja merupakan kelompokyang menggantungkan kehidupannya dan keluarganya kepada perusahaan tempatnya bekerja dan hamper semua pekerja yang dikenakan pemutusan hubungan kerja tidak dapat lagi bekerja di perusahaan lain yang disebabkan oleh beberapa hal seperti masalah umur dan lapangan kerja yang terbatas, yang artinya hak-hak pekerja seperti pesangon merupakan modal utama untuk melanjutkan hidup untuk kehidupan pekerja dan keluarganya.

Bila dibandingkan dnegan piutang-piutang negara seperti pajak, tentunya posisi pekerja sangat lebih lemah dan lebih penting untuk didahulukan bagi pekerja, mengingat pajak itu pun secara hukum akan tetap dikembalikan untuk kepentingan masyarakat yang tentunya termasuk pekerja di dalamnya. Sangat tidak logis piutang negara diutamakan dibanding pekerja karena bagaimanapun negara bertanggung jawab secara konstitusional terhadap jaminan hidup yang layak bagi warga negara termasuk pekerja. Penelitian ini menggunakan metode pendekatan yuridis normatif. Pendekatan ini dipilih mengingat dalam rangka mencapai tujuan penelitian/ target penelitian peneliti mengacu kepada norma-norma hukum yang terdapat dalam peraturan perundang-undangan, putusanputusan pengadilan serta norma-norma hukum yang ada dalam masyarakat. ${ }^{8}$

Berdasarkan prinsip perlakuan khusus terhadap pihak yang lemah maka sudah selayaknya dan sepatutnya hak pekerja didahulukan dari semua kreditur lainnya.

8 Dewi Tuti Muryati (n 2).Op.Cit.[16]. 
Berdasarkan hal-hal tersebut di atas maka ketentuan Pasal 95 ayat (4) UU Nomor 13/2003 tentang Ketenagakerjaan sepanjang frasa "didahulukan pembayarannya" menimbulkan ketidakpastian hukum dan bertentangan dengan Pasal 28D (1) UUD 1945 yang menjamin akan adanya suatu kepastian hukum.

\section{Prinsip Khusus UU Kepailitan dan PKPU}

Pada pertengahan tahun 1997 perekonomian nasional mendapat ujian dengan terjadinya krisis moneter. Hal ini berdampak besar pada jatuhnya dunia usaha. Menghadapi situasi ini, pemerintah sebagai ujung tombak pembentukan hukum nasional mencari jalan keluar secara adil, cepat, terbuka dan efektif dengan mempersiapkan perangkat hukum yang mendukung yaitu dengan cara merevisi, merubah dan menghapus beberapa pasal dalam peraturan tentang kepailitan yang semula diatur dalam peraturan kepailitan atau failissement verordening. ${ }^{9}$

Kelahiran dari hukum kepailitan Indonesia yang berlaku saat ini merupakan hasil kesepakatan antara Pemerintah Indonesia dengan pihak Internasional Monetary Fund (IMF) yang tertuang dalam Appendix VII of Letter. Kesepakatan pihak krisis moneter ini di kemudian hari melahirkan Peraturan Pemerintah Pengganti Undang-Undang (Perpu) No. 1 Tahun 1998 tentang Perubahan Atas undangUndang Kepailitan pada tanggal 22 April 1998 dan dinyatakan berlaku efektif sejak tanggal 20 Agustus 1998. Perpu ini adalah peraturan kepailitan versi krisis moneter Indonesia yang melakukan perubahan kilat dan instan atas Faillissements Verordening atau Ordonansi Kepailitan dalam Weboek van Rechtsvordering atau Kitab Undang-undang hukum Dagang (KUHD) yang berlaku sejak tanggal 1 Mei 1948 (Stb. 1847 No. 23).

Perpu No. 1 Tahun 1998 tentang Perubahan atas Undnag-Undang Kepailitan tersebut diserahkan dan diundangkan menjadi Undang-Undang No. 4 tahun 1998 tentang Kepailitan dan Penundaan Pembayaran Utang pada tanggal 9 September 1998. Kurang lebih 6 tahun berikutnya, Undang-Undang No. 4 Tahun 1998 direvisi

9 Sriti Hesti Astiti, 'Pertanggungjawaban Pidana Kurator Berdasarkan Prinsip Independensi Menurut Hukum Kepailitan’ (2016) 31 Yuridika.[441]. 
dan diubah menjadi Undang-Undang No. 37 Tahun 2004 tentang Kepailitan dan PKPU yang berlaku di Indonesia sejak tanggal 18 Oktober 2004 hingga saat ini. Jika ditelusuri dari tahun pembentukannya, UU Kepailitan dan PKPU yang berlaku pada saat ini tunduk pada ketentuan yang diatur oleh Pasal 5 Undang-Undang Nomor 10 tahun 2001 tentang Pembentukan Peraturan Perudang-Undangan, yang mensyaratkan setiap pembentukan peraturan perundang-undangan haruslah berdasarkan asas pembentukan peraturan perundang-undangan yang baik, yaitu :

- Asas Kejelasan Tujuan;

- Asas keseimbangan atau oragn pembentuk yang tepat;

- Asas kesesuaian antara jenis dan materi muatan;

- Asas dapat dilaksanakan;

- Asas kedayagunaan dan kehasilgunaan;

- Asas kejelasan rumusan;

- Asas keterbukaan.

Sedangkan untuk substansi, UU kepailitan dan PKPU tunduk pada 10 prinsip sebagaimana diatur dalam Pasal 6 Undang-Undang Nomor 10 Tahun 2001 tentang Pembentukan Peraturan Perundang-Undangan yaitu:

- Asas pengayoman;

- Asas kemanusiaan;

- Asas kebangsaan;

- Asas kekeluargaan;

- Asas kenusantaraan;

- Asas Kebineka tunggal Ika;

- Asas keadilan

- Asas kesamaan kedudukan dan kepastian hukum;

- Asas ketertiban dan kepastian hukum;

- Asas keseimbangan, keserasian dan keselarasan.

Latar belakang lahirnya UU Kepailitan dan PKPU dipicu oleh krisis moneter dan tekanan institusi keuangan internasional (IMF) terhadap Indonesia yang menilai Ordonansi Kepailitan yang berlaku di Indonesia tidak lagi dapat digunakan untuk mengatur tata cara penyelesaian pembayaran utang di saat krisis moneter. Jika ditinjau latar belakang kelahirannya, mestinya norma-norma yang dikandung dalam UU Kepailitan dan PKPU menjawab tuntutan etis dan kebutuhan sosial ekonomi dari masyarakat Indonesia. Bernard Nainggolan dalam penelitiannya mendapatkan hanya 4 dari 7 asas pembentukan perundang-undangan yang diatur dalam Pasal 5 
UU Nomor 10 tahun 2001 tentang Pembentukan Peraturan Perundang-Undangan yang tidak dipenuhi dalam pembentukkan UU Kepailitan dan PKPU. Keempatan asas tersebut adalah: ${ }^{10}$

- Asas kejelasan tujuan;

- Asas dapat dilaksanakan;

- Asas kejelasan rumusan;

- Asas keterbukaan.

Terlepas dari ketiadaan empat asas sebagaimana dimaksud oleh Bernard Nainggolan tersebut, sebagimana telah dibahas sebelumnya, bahwa UU Kepailitan dan PKPU telah mengadopsi 9 prinsip universal kepailitan, yaitu:

- Prinsip concursus creditorum;

- Prinsip insolvent;

- Prinsip Paritas Creditorum;

- Prinsip Pari Pasu Pro Rata Parte;

- Prinsip Debt collection;

- Prinsip utang sudah jatuh tempo dan dapar dibayar;

- Prinsip debitor kehilangan hak mengurus harta bendanya;

- Prinsip transparansi;

- Prinsip separate legal entity.

Selain itu, UU Kepailitan dan PKPU secara eksplisit, dalam BAB Penjelasan UU Kepailitan dan PKPU, menyebutkan prinsip khusus dari UU Kepailitan dan PKPU. Dalam Penjelasan disebutkan latar belakang dari diperlukannya undangundang baru tentang kepailitan dan PKPU yang merupakan produk hukum nasional yang sesuai dengan kebutuhan dan perkembangan hukum masyarakat. Secara formal, BAB penjelasan menyebutkan ada 4 prinsip atau asas yang dikandung oleh UU Kepailitan dan PKPU. Prinsip-prinsip tersebut sebagai berikut:

1. Prinsip Keseimbangan.

Prinsip Keseimbangan dalam menyelesaikan pembayaran utang-piutang bertujuan untuk mencegah segala bentuk penyalah gunaan pranata kepailitan untuk tujuan-tujuan di luar yang dicita-citakan oleh UU Kepailitan dan PKPU. Tujuan Kepailitan yang dicita-citakan oleh UU Kepailitan dan PKPU tidak

\footnotetext{
${ }^{10}$ Bernard nainggolan, Perlindungan Hukum Seimbang Debitor, Kreditor Dan Pihak-Pihak Berkepentingan Dalam Kepailitan (Alumni 2011).[121].
} 
hanya sekedar mengatur tata cara pembayaran utang melalui jalur penundaan pembayaran utang (PKPU atau reorganisasi utang). Dalam penjelasan Umum UU Kepailitan dan PKPU difungsikan sebagai sarana hukum untuk menopang pembangunan perekonomian nasional. Secara khusus sebagai sarana penyelesaian masalah utang piutang yang dilaksanakan secara adil, cepat, terbuka dan efektif.

Dalam bab Penjelasan umum UU Kepailitan dan PKPU disebutkan secara eksplisit ada 3 tujuan pembentukan UU Kepailitan dan PKPU, yaitu:

1) Untuk menghindari perebutan harta debitor apabila dalam waktu yang sama ada beberapa kreditor yang menagih piutangnya dari debitor;

2) Untuk menghindari adanya kreditor pemenang hak jaminan kebendaan yang menuntut haknya dengan cara menjual barang milik debitor tanpa memperhatikan kepentingan debitor atau kreditor lainnya;

3) Untuk menghindari adanya kecurangan-kecurangan yang dilakukan oleh salah seorang kreditor atau debitor sendiri.

Berdasarkan tujuan dari UU Kepailitan dan PKPU tersebut di atas, dapat disimpulkan bahwa UU Kepailitan dan PKPU ditujukan oleh pembentuk undang-undang sebagai sarana penyelesaian masalah pembayaran utangpiutang. UU kepailitan dan PKPU tergolong sebagai hukum formil. Sebagai hukum formil, maka kaidah hukum kepailitan bersifat imperative atau a priori. Sifat a priori tersebut dapat dilihat dalam pengaturan syarat-syarat kepailitan maupun pengajuan permohonan penundaan pembayaran utang (PKPU) yang diatur dalam Pasal 2 ayat (1) jo. Pasal 8 Ayat (4), Pasal 222 jo Pasal 229 ayat (3) UU Kepailitan dan PKPU.

\section{Prinsip kelangsungan Usaha}

Prinsip kelangsungan usaha (going concern) merupakan ciri-ciri dari hukum kepailitan modern yang mengisi ketiadaan pengaturan pemberian penghapusan utang (debtrecharge) dan pemberian fresh start bagi debitor dalam UU Kepailitan dan PKPU. Berdasarkan prinsip kelangsungan usaha, kepailitan sebagai sita umum atas harta debitor tidak serta merta menghentikan operasional usaha 
debitor yang masih berstatus going concern. Prinsip kelangsungan usaha debitor bahkan dapat diterapkan oleh kurator sesaat setelah putusan pailit diucapkan, sebagaimana terkandung dalam Pasal 104 UU Kepailitan dan PKPU. Terhitung sejak debitor dinyatakan pailit, UU Kepailitan dan PKPU memberi kewenangan pada kurator untuk melanjutkan usaha debitor tetap beroperasi.

3. Prinsip keadilan

Prinsip keadilan yang dimaksud oleh UU Kepailitan dan PKPU adalah keadilan bagi semua pihak yang terkait kepentingannya dengan kepailitan debitor. Hal ini bermakna bahwa keadilan tidak hanya ditujukan kepada kreditor semata, akan tetapi kepada debitor maupun pihak ketiga yang terimbas atau terkait dengan kepailitan debitor. Misalnya para pekerja debitor atau pihak ketiga lainnya. Prinsip keadilan ini bertujuan mencegah kesewenang-wenangan kreditor yang berkepentingan langsung dengan harta pailit. Oleh karena itu, UU Kepailitan dan PKPU mengatur perlakuan yang seimbang (equal treatment) dalam proses pembayaran utang yang dilakukan dengan jalur kepailitan maupun jalur PKPU.

4. Prinsip Integrasi

Asas integrasi dalam undang-undang ini mengandung pengertian bahwa sistem hukum formil dan hukum materilnya merupakan satu kesatuan yang utuh dari sistem hukum perdata dan hukum acara perdata nasional yang berlaku sebagai hukum positif di Indonesia. UU Kepailitan dan PKPU adalah lex specialist yang mengatur prosedur pembayaran utang yang dilakukan dengan cara:

a. Mengajukan permohonan pailit, dan

b. Mengajukan permohonan PKPU.

Pada dasarnya, teori hukum yang mendasari undang-undang kepailitan tetap bertumpu pada teori hukum yang mendasari undang-undang kepailitan tetap bertumpu pada teori tujuan hukum pada umumnya, terutama teori etis dan teori utility. Berdasarkan teori etis, hukum dibuat untuk satu tujuan yaitu memberikan keadilan. Para ahli hukum pada umumnya berkiblat pada teori keadilan dari Aristoteles yang membagi keadilan menjadi keadilan distributive (distributive justice) dan keadilan komutatif (remedial justice). Keadilan distributif berangkat 
pada prinsip suum cuique tribuere yang bermakna setiap orang mendapatkan apa yang menjadi haknya. Keadilan berdasarkan prinsip suum cuique tribuere adalah keadilan subjektif. Sedangkan keadilan distributive berpijak pada prinsi keseimbangan yang keadilan bagi semua orang yang bersifat umum. ${ }^{11}$

Namun demikian, keadilan bukanlah tujuan akhir dari hukum, karena keadilan saja tidak menjadi jaminan terciptanya ketertiban di tengah-tengah masyarakat. Keadilan distributive yang bersifat individualistik tentunya akan berhadapan dengan kepentingan pihak lain atau kepentingan umum. Lagi pula, keadilan distributife belum tentu memuaskan perasaan subjektif setiap orang. Oleh karena itu, di samping teori etis, hukum kepailitan juga ditopang oleh teori utility yang dipelopori oleh Jeremy bentham. Teori utiliti mengusung pemikiran bahwa hukum bertujuan menjamin kebahagiaan terbesar bagi sebanyak-banyaknya manusia atau hukum menjamin kebahagiaan tiap individu. ${ }^{12}$

Adapun Hadi Subhan menyebutnya ada 6 prinsip umum hukum kepailitan. ${ }^{13}$ Sedang Elyta Ras Ginting cenderung berpendapat dari 10 prinsip yang diuraikan Roy Goode tersebut, secara umum dapat direduksi menjadi 9 prinsip hukum kepailitan yang umum berlaku di seluruh dunia tanpa membeda-bedakan sistim hukum yang berlaku. Prinsip umum kepailitan tersebut, antara lain:

\section{Prinsip Concursus Creditorium}

Dimana prinsip ini berbicara tentang sita umum atas harta debitor hanya dapat diterapkan jika debitor memiliki lebih dari satu kreditor dan nilai keseluruhan harta benda milik debitor tidak mencukupi untuk membayar seluruh utangnya tersebut. Dari sudut yuridis, debitor yang tidak memenuhi prestasinya untuk membayar utangnya sesuai dengan kesepakatan menjadi alasan hukum bagi kreditor untuk menuntut di pengadilan dengan gugatan wanprestasi. Fakta bahwa debitor tidak membayar utang tidak menjadi alasan hukum untuk

\footnotetext{
11 ibid.[23-24].

12 Elyta Ras Ginting, Hukum Kepailitan Teori Kepailitan (Sinar Grafika 2018).[79].

${ }_{13}$ M. Hadi Subhan, Hukum Kepailitan: Prinsip, Norma, Dan Praktik Di Peradilan (Prenanda Media Group 2008).[353].
} 
menyatakan debitor dalam keadaan pailit. Debitor yang tidak membayar utangnya yang sudah jatuh tempo hanya dapat dikenakan sita umum manakala debitor memiliki lebih dari seorang kreditor.

Sedangkan tuntutan pelunasan utang debitor dengan menggunakan pranata sita umum hanya dapat diterapkan bagi debitor yang memiliki lebih daru dua kreditor dan tidak mengandung sengketa. Pasal 2 Ayat (1) UU Kepailitan dan PKPU, mensyaratkan concursus creditorum sebagai syarat formal untuk mengajukan permohonan pailit sebagai berikut:

Debitor yang mempunya dua atau lebih kreditor dan tidak membayar lunas sedikitnya satu utang yang telah jatuh waktu dan dapat ditagih, dinyatakan pailit dengan putusan pengadilan, baik atas permohonannya sendiri maupun atas permohonan satu atau lebih kreditornya.

2. Prinsip Insolven

Dari sudut ilmu ekonomi, keadaan insolven adalah suatu kondisi dimana kewajiban debitor lebih besar dari nilai seluruh hartanya. Kondisi debitor yang demikian dinilai sudah dalam keadaan tidak sanggup membayar seluruh utangnya atau keadaan insolven sebenarnya menjadi jatung dari kepailitan. ${ }^{14}$ Keadaan insolven menjadi salah satu alasan penting mengapa harta benda debitor harus disita secara umum dan mengapa seluruh kegiatan usaha maupun tuntutan hukum terhadap harta debitor harus disita secara umum dan mengapa seluruh kegiatan usaha maupun tuntutan hukum terhadap harta dibetor dibekukan sejak saat debitor dinyatakan pailit. Tujuan penghentian dan pembekuan segala kegiatan yang berkaitan dengan harta debitor adalah agar harta debitor tidak makin berkurang jumlah maupun nilainya yang berakibat akan makin merugikan para kreditornya. Keadaan insolven merupakan alasan hukum untuk membatalkan perikatan yang dilakukan debitor sebelum dinyatakan pailit dengan gugatan actio pauliana.

Pada umumnya hukum kepailitan yang berlaku di dunia ini menjadikan

${ }^{14}$ Michael Murray and Jason Harris, Keay's Insolvency (Personal and Corporate Law and Principle) (Thomson Reuters (Professional) Autralian Limited 2014).[15]. 
keadaan insolven sebagai syarat yang harus dipenuhi agar debitor dapat dinyatakan pailit. Keadaan insolven tersebut mula-mula dimohonkan kepada pengadilan yang akan mengeluarkan penetapan debitor dalam keadaan insolven. Penetapan pengadilan bahwa debitor berada dalam keadaan insolven menjadi dasar permohonan pailit atau mengajukan permohonan reorganisasi utang. Tanpa ada penetapan insolven dari pengadilan, debitor tidak dapat dinyatakan pailit oleh pengadilan. Dengan kata lain, kondisi debitor telah insolven menjadi pintu masuk pada kepailitan.

\section{Prinsip Paritas Creditorum}

Prinsip Paritas Creditorum atau structured creditors berkaitan dengan keseimbangan kepentingan seluruh kreditor untuk mendapatkan pembayaran dari harta pailit. Prinsip Paritas Creditorum terkandung dalam norma yang diatur dalam Pasal 1112 dan 1113 KUH Perdata, yang mengatur tingkat kedudukan para kreditor berikut tingkat pembayaran pada masing-masing golongan kreditor. Prinsip ini berakar pada asas pari pasu (aqual sharing) yang menempatkan seluruh harta debitor yang ada maupun yang aka nada kemudian menjadi jaminan atas seluruh perikatan yang diperbuatnya.

Berdasarkan asas pari pasu tersebut, undang-undang memberikan hak prioritas pembayaran dari harta debitor kepada kreditor yang memiliki hak in rem atas harta benda debitor. Golongan yang diprioritaskan pembayaran piutangnya dari harta debitor adalah para kreditor yang perikatannya dengan debitor dijamin dengan hak kebendaan seperti gadai, hipotek, hak tanggungan, fidusia, hak retensi dan sebagainya. Prinsip paritas creditorum terkandung dalam Pasal 55 ayat (1) UU Kepailitan dan PKPU yang mengatur bahwa kreditor pemegang hak jaminan kebendaan dapat mengeksekusi sendiri haknya atas harta pailit yang menjadi jaminan piutangnya seolah-olah tidak terjadi kepailitan atas debitor.

Ada pula golongan kreditor yang tidak memiliki hak in rem atas harta debitor, namun undang-undang yang berlaku memberinya keistimewaan untuk didahulukan pembayarannya, bahkan didahulukan untuk dilunasi terlebih dahulu daripada piutang kreditor yang memiliki hak in rem atas harta debitor. Golongan 
kreditor yang demikian dikenal sebagai kreditor preferen, dan tagihannya disebut sebagai piutang preferen, misalnya tagihan pajak, biaya lelang dan sebagainya. Tagihan kreditor preferen oleh undang-undang yang berlaku wajib didahulukan pembayarannya. ${ }^{15}$

Golongan kreditor lainnya adalah kreditor konkuren yang terikat kesepakatan atau perikatan dengan debitor, akan tetapi tidak memiliki hak in rem atas harta debitor yang disebut sebagai kreditor konkuren. Golongan kreditor konkuren memang tidak memilii hak in rem atas harta pailit, namun memiliki hak in personam berdasarkan asas konsensus dan pacta sunt servanda dengan debitor. Perikatan kreditor konkuren dengan debitor diikat berdasarkan asas pari pasu yang diatur secara umum dalam Pasal 1131 KUHPerdata. Pemenuhan hak tagih kreditor konkuren berdasarkan asas pari pasu, didasarkan pada asas universal keadilan yaitu pacta sun servanda. Oleh karena itu, meskipun perikatan kreditor konkuren dengan debitor tidak diikuti dengan perjanjian pemberian jaminan kebendaan milik debitor, demi hukum kreditor berhak untuk mendapatkan pelunasan piutangnya dari harta debitor. Jika debitor pailit, UU Kepailitan dan PKPU, memberi hak voting husus hanya kepada kreditor konkuren untuk menerima atau menolak proposal perdamaian yang diajukan oleh debitor yang menghendaki kepailitannya diakhiri dengan pembayaran secara damai dengan para kreditor konkurennya. ${ }^{16}$ Hak mengeluarkan suara (voting) tersebut tidak diberikan kepada kreditor separatis, kecuali kreditor separatis menangggalkan hak separatisnya dan berposisi sebagai kreditor konkuren. ${ }^{17}$

\section{Prinsip Pari Pasu Pro Rata Parte}

Konsep pembayaran utang debitor berdasarkan prinsip Paritas creditorum hanya dapat dihidupkan pelaksanaannya dengan prinsip Pari Pasu Pro Rata Parte. Prinsip Pari Pasu Pro Rata Parte adalah prinsip yang menjadi penggerak

\footnotetext{
${ }^{15}$ Hak-hak kreditor preferen diatur dalam Pasal 60, Pasal 168 jo Pasal 189 ayat (4) huruf a dan Ayat (5) UU Kepailitan dan PKPU.

${ }^{16}$ Perhatikan Pasal 151 UU Kepailitan dan PKPU.

${ }^{17}$ Pasal 149 UU Kepailitan dan PKPU.
} 
prinsip paritas creditorum diterapkan jika debitor menjadi pailit sementara harta debitor tidak mencukupi untuk membayar seluruh kewajibannya. Pari pasu bermakna kreditor bersama-sama memperoleh pelunasan utang tanpa ada yang didahulukan (aqual sharing). ${ }^{18}$ Sedangkan pro rata parte bermakna perolehan yang proporsional,yaitu jumlah yang diterima kreditor dihitung berdasarkan pada besarnya piutang masing-masing dibandingkan dengan piutang mereka secara keseluruhan terhadap harta kekayaan debitor.

\section{Prinsip Debt Collection}

Prinsip Debt Collection merupakan satu kesatuan yang berkaitan langsung dengan prinsip concursus creditorium dan keadaan insolven. Prinsip Debt Collection bersama-sama dengan concursus creditorum menjadi penanda untuk membedakan mana tuntutan pembayaran utang yang dapat dilakukan dengan gugatan perdata (wanprestasi atau perbuatan melawan hukum) dengan tuntutan pembayaran utang yang harus dilakuakn dengan permohonan pailit.

6. Utang Sudah Jatuh Tempo dan Dapat Dibayar

7. Debitor Kehilangan Hak Mengurus Harta Bendanya

8. Prinsip Transparansi

9. Prinsip Separate Legal Personality

\section{Tanggung Jawab Kurator Terhadap Hak Pekerja Berdasarkan Pasal 95 Ayat}

\section{(4) UU Ketenagakerjaan Terhadap Putusan MK Nomor 67 Tahun 2013}

Kurator dalam membereskan harta pailit perlu mempertimbangkan aturan perundang-undangan yang berlaku. Pembagian harta pailit terhadap para kreditor, baik kreditor Separatis, Preferen ataupun Konkuren telah mengalami tumpang tindih. Ada juga pasal yang mengatakan bahwa kreditur separatis itu untuk pembagian harta kepailitan sudah disendirikan, jadi adanya kepailitan dan ketidak pailitan tidak memberi dampak yang signifikan pada kreditur separatis.

\footnotetext{
${ }^{18}$ Michael Murray and Jason Harris (n 14). Op. Cit. [13] dan [33].
} 
Sebelum menguraikan lebih jauh mengenai ketiadaan kepastian hukum terhadap kondisi tersebut sehingga memberi dampak bagi pekerja/buruh selaku kreditor Preferen, yang dalam hal ini sangat dalam posisi rentan. Alangkah baiknya jika membahas dasar hukum adanya Kreditor Preferen.

Pekerja sebagai kreditor Preferen, telah diatur dalam KUH Perdata. Adapun aturan tersebut diantaranya:

Pasal 1133 KUH Perdata

"Hak untuk didahulukan di antara orang-orang berpiutang terbit dari hak istimewa, dari gadai dan dari hipotek".

Pasal 1134 KUH Perdata

"Hak Istimewa adalah suatu hak yang diberikan oleh undang-undang kepada seorang kreditor yang menyebabkan ia berkedudukan lebih tinggi daripada yang lainnya, semata-mata berdasarkan sifat piutang itu. Gadai dan hipotik lebih tinggi daripada hak istimewa, kecuali dalam hal undang-undang dengan tegas menentukan kebalikannya".

Bunyi dari redaksi Pasal 1133 ayat (1) KUH Perdata di atas sangat singkat dan sederhana, namun ada beberapa ada substansi juridis yang dikandung oleh Pasal 1133 ayat (1) KUH Perdata yakni sebagai berikut :

- Mengatur tentang 2 jenis piutang atau kreditor, yaitu kreditor yang memiliki hak istimewa untuk didahulukan pembayarannya yang disebut sebagai kreditor preferen dan kreditor separatis.

- Mengatur tentang piutang yang memiliki hak untuk didahulukan pembayarannya ada 2 yaitu piutang yang terbit dikarenakan jenis tagihannya diistimewakan oleh undang-undang dan piutang yang didahulukan pembayarannya yang terbit dari hak kebendaan seperti gadai atau hipotik (hak tanggungan) berdasarkan perjanjian.

Pengertian hak istimewa (prevelage) dari kreditor Preferen diatur dalam Pasal 1134 ayat (1) KUH Perdata, yaitu suatu hak yang oleh undang-undang diberikan kepada seorang berpiutang sehingga tingkatannya lebih tinggi daripada orang berpiutang lainnya, semata-mata berdasarkan sifat piutangnya. Makna yang terkandung dalam Pasal 1134 Ayat (1) KUH Perdata adalah bahwa kreditor preferen lebih tinggi kedudukannya dari kreditor lainnya dikarenakan undang-undang sendiri 
memberi perlakuan istimewa. Adapun yang dimaksud dengan "kreditor lainnya" adalah kreditor konkuren, termasuk kreditor separatis, karena meskipun Pasal 1134 Ayat (2) KUH Perdata, menyatakan bahwa kedudukan kreditor separatis lebih tinggi daripada kreditor konkuren, namun ketinggian derajatnya tersebut hanya berlaku sepanjang tidak dikecualikan oleh undang-undang. Jika undang-undang mengecualikannya, maka tagihan dari kreditor preferen yang diistimewakan untuk didahulukan pembayarannya dari pada tagihan kreditor separatis.

Keistimewaan pembayaran tagihan preferen tertuang dalam pasal 60 ayat (2) UU Kepailitan dan PKPU, dimana kreditor separatis yang menjalankan hak parate eksekusi atas barang jaminan diwajibkan menyerahkan bagian dari tagihan preferen yang timbul atas penjualan barang jaminan tersebut kepada curator atau langsung dibayarkan kepada kreditor preferen yang bersangkutan sebelum mengambil bagian untuk pelunasan tagihannya.

Pada prinsipnya pasal 1138 KUH Perdata membagi hak tagih istimewa dari kreditor preferen dalam dua kategori yaitu: prevelege khusus sebagai hak istimewa untuk didahulukan pembayarannya atas penjualan benda-benda tertentu. Kedua prevelege umum sebagai hak untuk didahulukan pembayarannya atas benda bergerak dan tidak bergerak berdasarkan urutannya. Privelege khusus dan umum tersebut memiliki ketingkatannya sendiri untuk didahulukan pembayarannya berdasarkan prinsip privilege khusus mendahului privilege umum.

Dalam bukunya, J.B Huizink mendefinisikan kreditor preferen sebagai kreditor yang tagihannya terkait pada prioritas untuk membedakannya dengan kreditor konkuren. Hak didahulukan atau privilege timbul hanya dari undangundang, sebagai kebalikan dari prioritas yang terkait pada gadai atau hipotik yang sifatnya diperjanjikan. ${ }^{19}$ Hal yang sama juga dikemukakan oleh Herowati Poesoko bahwa privilege bukan merupakan hak kebendaan, hanya merupakan hak untuk lebih mendahulukan dalam pelunasan/pembayaran piutang. ${ }^{20}$

\footnotetext{
${ }^{19}$ J.B. Huizink, Insoventie (Pusat Studi Hukum \& Ekonomi Fakultas hukum Universitas Indonesia 2004).[39].

${ }^{20}$ Herowati Poesoko, Parate Executie Obyek Hak Tanggungan (Inkonsistensi Konfili Norma Dan Kesesatan Penalaran Dalam UUHT) (LaksBang PRESSindo 2008).[82].
} 
Pasal 60 ayat (2) UU Kepailitan dan PKPU mengistimewakan tata cara pembayaran utang kepada kreditor preferen yang menempatkan tingkatan kedudukan kreditor preferen lebih tinggi daripada kreditor separatis. Dalam bab penjelasan Pasal 60 ayat (2) UU Kepailitan dan PKPU dijelaskan bahwa ${ }^{21}$ yang dimaksud dengan 'Kreditor yang diistimewakan'adalah kreditor pemegang hak sebagaimana dimaksud dalam Pasal 1139 dan Pasal 1149 KUH Perdata.

Sebagaimana dalam pelaksanaan putusan pailit kata "didahulukan" ditempatkan setelah pelunasan terhadap hak-hak negara dan para kreditor separatis yang merujuk buku dua Bab XIX KUH Perdata dan Pasal 21 UU Nomor 6 tahun 1983 yang diubah oleh UU Nomor 9 tahun 1994. Di sini hak negara ditempatkan sebagai pemegang hak posisi pertama, diikuti oleh kreditor separatis (pemegang hak tanggungan, gadai, fidusia hipotik).

Pun demikian juga berdasarkan Pasal 95 ayat (4) UU nomor 13 tahun 2003 yang menempatkan hak-hak pekerja harus "didahulukan", akan tetapi dalam praktik ditempatkan dalam posisi setelah pemenuhan hak negara dan para kreditor separatis, menimbulkan adanya ketidakpastian hukum dalam penerapan Pasal 95 Ayat (4) UU Nomor 13 tahun 2003.

Hal ini dapat terjadi karena dalam bagian pembahasan makna dari pada didahulukan sendiri tidak dijelaskan secara ekplisit. Akhirnya yang terjadi adalah posisi buruh yang kurang memiliki tawar sebagaimana kreditor lain (walaupun dalam UU sudah diistimewakan) kerap kali pembayaran upah untuk para pekerja dinomor sekiankan setelah pembagian untuk kreditor separatis telah selesai.

Melihat kondisi yang seperti ini, berarti Pasal 95 ayat (4) UU Nomor 13 tahun 2003 tentang Ketenagakerjaan bertentangan dengan Pasal 28D Ayat (1) UUD 1945 karena berpotensi menimbulkan Ketidakpastian Hukum bagi pekerja. Adapun bunyi dari Pasal 28D Ayat (1) 1945 menyatakan:

"Setiap orang berhak atas pengakuan, jaminan, perlindungan, dan KEPASTIAN hukum yang adil serta perlakuan yang sama di hadapan hukum”.

${ }^{21}$ Elyta Ras Ginting (n 12).[175]. 
Adapun Pasal 95 Ayat (4) UU Nomor 13 tahun 2003 tentang Ketenagakerjaan menyatakan bahwasanya:

"Dalam hal perusahaan dinyatakan pailit atau dilikuidasi berdasarkan peraturan perundang-undangan yang berlaku, maka upah dan hak-hak lainnya dari pekerja/buruh merupakan utang yang didahulukan pembayarannya".

Pemberlakuan Pasal 95 Ayat (4) UU No 13/2003 berpotensi menimbulkan ketidakpastian hukum, mengingat tidak adanya penafsiran yang jelas dan tegas mengenai klausule "didahulukan pembayarannya".

Lon Fuller dalam bukunya the Morality of Law menyatakan 8 (delapan) asas yang harus dipenuhi oleh hukum, yang apabila tidak terpenuhi, maka hukum akan gagal untuk disebut sebagai hukum, atau dengan kata lain harus terdapat kepastian hukum. Kedelapan asas tersebut adalah sebagai berikut :

1. Suatu sistem hukum yang terdiri dari peraturan-peraturan, tidak berdasarkan putusan-putusan sesat untuk hal-hal tertentu;

2. Peraturan tersebut diumumkan kepada publik;

3. Tidak berlaku surut, karena akan merusak integritas sistem;

4. Dibuat dalam rumusan yang dimengerti oleh umum;

5. Tidak boleh ada peraturan yang saling bertentangan;

6. Tidak boleh menuntut suatu tindakan yang melebihi apa yang bisa dilakukan;

7. Tidak boleh sering diubah-ubah;

8. Harus ada kesesuaian antara peraturan dan pelaksanaan sehari-hari.

Pendapat Lon Fuller di atas dapat dikatakan bahwa harus ada kepastian antara peraturan dan pelaksanaannya, dengan demikian sudah memasuki ranah aksi, perilaku, dan faktor-faktor yang mempengaruhi bagaimana hukum positif dijalankan.

Sedangkan menurut Gustav Radbruch, hukum harus mengandung 3 nilai identitas, yakni sebagai berikut:

1. Asas Kepastian hukum (rechtmatigheid), asas ini meninjau dari sudut yuridis.

2. Asas Keadilan hukum (gerectigheit), asas ini meninjau dari sudut filosofis, dimana keadilan adalah kesamaan hak untuk semua orang di depan pengadilan.

3. Asas Kemanfaatan Hukum (zwechmatigheid)

Tujuan hukum yang mendekati realistis adalah kepastian hukum dan kemanfaatan hukum. Kaum Positivisme lebih menekankan pada kepastian hukum, sedangkan Kaum Fungsionalis mengutamakan kemanfaatan hukum, 
dan sekitarnya dapat dikemukakan bahwa "summum ius, summa injuria, summa lex, summa crux" yang artinya adalah hukum yang keras dapat melukai, kecuali keadilan yang dapat menolongnya, dengan demikian kendatipun keadilan bukan merupakan tujuan hukum satu-satunya akan tetapi tujuan hukum yang paling substantive adalah keadilan.

Menurut Utrecht, kepastian hukum mengandung dua pengertian, yaitu adanya aturan yang bersifat umum membuat individu mengetahui perbuatan apa yang boleh atau tidak boleh dilakukan, dan yang kedua adalah berupa keamanan hukum bagi individu dari kesewenangan pemerintah karena dengan adanya aturan yang bersifat umum itu individu dapat mengetahui apa saja yang boleh dibebankan atau dilakukan oleh Negara terhadap individu.

Dalam praktik dan dengan mengingat ketentuan hukum yang berlaku, baik itu dalam Pasal 1134 ayat (2) juncto Pasal 1137 KUH Perdata dan Pasal 21 UU Nomor 16/2000 tentang ketentuan umum dan tata cara perpajakan sebagaimana telah diubah terakhir dengan UU Nomor 28/2007 tentang perubahan ketiga atas UU No. 6/1983 tentang ketentuan Umum dan tata cara perpajakan, maka terdapat urutan peringkat penyelesaian tagihan kreditor setelah selesainya kreditor separatis, dimana upah buruh masih harus menunggu urutan setelah tagihan hak negara, kurator lelang, dan badan umum yang dibentuk Pemerintah untuk didahulukan. Padahal berdasarkan Pasal 95 ayat (4) UU No 13/2003, secara hukum adanya pailit terhadap perusahaan, dalam hal pemenuhan hak-hak pekerja seperti pesangon dan hak-hak lainnya harus didahulukan dari pemenuhan kewajiban perusahaan yang pailit.

Dalam Pasal 1149 KUH Perdata, piutang buruh terhadap perusahaan/majikan berkedudukan sebagai kreditor/piutang preferen, sehingga dengan dinyatakan pailitnya debitor tidak akan menghilangkan hak-hak buruh sebagai kreditor terhadap perusahaan tersebut. Buruh dapat menuntut pembayaran upahnya sebagai kreditor dengan mengajukan tagihan kepada curator yang ditunjuk oleh Pengadilan Niaga yang bertugas untuk mengurus dan membereskan harta debitor pailit. Curator mendahulukan pembayaran upah buruh sebagai kreditor preferen dari hasil penjualan boedel pailit daripada pembayaran kepada kreditor konkuren.. 
Dengan tidak adanya jaminan kepastian hukum bagi pekerja sebagaimana diuraikan di atas maka ketentuan Pasal 95 ayat (4) UUD 13/2003 tentang Ketenagakerjaan sepanjang frasa "didahulukan pembayarannya" telah nyata menimbulkan multi tafsir dan menempatkan pekerja/buruh dalam posisi yang lemah dan tidak equal dengan para kreditor separatis yang dalam praktik lebih didahulukan pembayarannya.

Dalam konsideran menimbang UU Nomor 13/2003 menyatakan, "pembangunan nasional dilaksanakan dalam rangka pembangunan manusia Indonesia seutuhnya dan pembangunan masyarakat Indonesia seluruhnya untuk mewujudkan masyarakat yang sejahtera, adil, makmur, yang merata, baik materiil maupun spiritual berdasarkan Pancasila dan UUD NRI tahun 1945, ”. Dan cita-cita sebagaimana dalam konsideran menimbang tersebut terlaksana apabila ketentuan Pasal 95 ayat (4) UU No. 13/2003 sepanjang frasa "didahulukan pembayarannya" diartikan pembayarannya didahulukan daripada para kreditor separatis pemegang jaminan gadai, fidusia dan hak tanggungan.

Ketidakpastian hukum siapa yang didahulukan sangatlah menimbulkan ketidakpastian hukum bagi pekerja sehingga perlu untuk di tafsirkan oleh Mahkamah Konsstitusi. Oleh karenya, saat ini terdapat beberapa perkembangan mengenai piutang preferen yang terjadi di luar KUH Perdata maupun UU yang disebutkan di atas. Putusan MK Nomor 67/PUU-VI/2013 menempatkan pembayaran upah pekerja sebagaimana diatur dalam pasal 95 ayat (4) UU Nomor 13/2003 tentang Ketenagakerjaan mendahului tagihan hak negara, kantor lelang dan badan umum yang dibentuk pemerintah, utang pajak, dan tagihan kreditor separatis manakala pengusaha pailit. Sedangkan pembayaran hak-hak pekerja/lainnya didahulukan atas semua tagihan termasuk tagihan hak negara, kantor lelang, dan badan umum yang dibentuk oleh pemerintah, kecuali tagihan dari kreditor separatis. Dengan demikian, putusan MK menempatkan posisi upah pekerja lebih tinggi kedudukannya dan lebih preferen atau istimewa dari semua jenis tagihan, bahkan tagihan negara atas pajak dan tagihan kreditor separatis. MK beralasan bahwa upah pekerja yang belum dibayar oleh debitor sebelum dinyatakan pailit merupakan hak dasar pekerja yang 
tidak boleh dihapus maupun dikurangi. ${ }^{22}$

\section{Hukum Inklusif Memandang Putusan MK NOMOR 67 Tahun 2013 Dalam Pembagian Upah Pekerja/Buruh}

Sekian banyak perusahaan di Indonesia yang mengalami kepailitan, seringkali harta pailit yang dibagikan oleh Kurator atau dari debitor kepada Kreditor baik kreditor Separatis, Kreditor Preferen maupun Kreditor Konkuren seringkali tidak mencukupi pembayaran hutang debitor. Oleh karenanya, hadirnya Hukum Kepailitan Nomor 67 tahun 2004 bukan menjadikan matinya sebuah usaha, melainkan untuk menyelamatkan kondisi debitor yang terlilit hutang, maupun posisi kreditor yang memiliki harapan cemas atas ketidak pastian harta yang dihutangkan untuk dikembalikan.

Karena ketidak cukupannya harta debitor untuk melunasi hutangnya kepada kreditor tersebut menjadikan para kreditor mengalami perebutan harta pailit. Alhasil, kreditor yang memiliki posisi tawar yang begitu lemah tidak memiliki akses untuk memperoleh haknya. Hal ini adalah Pekerja/Buruh yang menempati posisi sebagai kreditor preferen yang dilindungi posisinya oleh UU Ketenagakerjaan, termasuk di dalamnya adalah Pasal 95 Ayat (4).

Namun, Pasal 95 Ayat (4) UU Ketenagakerjaan sendiri mengalami perluasan pemaknaan tersebut dikarenakan di bagian penjelasan tidak dijelaskan secara eksplisit makna klausule “...didahulukan" sehingga praktik di lapangan jika perusahaan pailit, posisi buruh dalam hal ini banyak di posisikan sebagai kreditor konkuren. Dimana kreditur ini adalah perolehan pembayaran utang dari hasil sisa setelah pembayaran pada kreditur preferen atau kreditur yang diistimewakan sudah terbayarkan.

Menurut Pasal 95 ayat (4) UU Ketenagakerjaan, dan Pasal 1149 KUH Perdata, upah dan uang pesangon merupakan piutang yang diikat dengan hak istimewa. Walaupun sifat dari hak istimewa didahulukan, posisi pemegang hak istimewa

\footnotetext{
22 ibid. [183].
} 
masih berada di bawah pemegang hak gadai dan hipotek. Bahkan dalam barisan kreditor pemegang hak istimewa, pekerja/buruh berada di peringkat kelima setelah tagihan pajak, biaya perkara, biaya lelang, dan biaya kurator. ${ }^{23}$

Memandang akar permasalahan tersebut, maka Pasal 95 Ayat (4) diajukan ke Mahkamah Konstitusi untuk dilakukan uji materil, sehingga menghasilkan Putusan MK Nomor 67/PUU-XI/2013. Putusan MK ini sebagaimana dijelaskan pada sub bab di atas, sejalan dengan teori hukum Inklusif yang berhasil dicetuskan oleh Jawahir Thontowi.

Hukum Inklusif memerlukan landasan pemikiran yang lebih kritis obyektif, kreatif, inovatis dan komprehensif. Sebagaimana diketahui, hukum nasional demikian juga Pasal 95 Ayat (4) UU Ketenagakerjaan belum mampu menyentuh masyarakat yang secara konstitusional telah dilindungi hak-haknya, termasuk hak memperoleh upah layak dan setiap orang berhak untuk mendapatkan imbalan dan perlakuan yang adil dan layak dalam hubungan kerja, sebagaimana yang termaktub dalam Pasal 27 huruf b dan Pasal 28D UUD 1945.

Dengan hadirnya hukum inklusif maka mampu terlahirlah kebijakan hukum dan politik yang mampu bekerja secara berkeadilan. Di sini hukum inklusif juga dapat dijadikan pedoman bagi manusia dalam berkehidupan masyarakat dan bernegara untuk tercapainya ketertiban social (social order) dan kedamaian hidup (peaceful life), serta dapat mempertahankan kehormatan atau martabat pribadi dan keluarga, suku bangsa dan agama, serta memfasilitasi peran apparat penegak hukum yang berwibawa. ${ }^{24}$

Jawahir menyampaikan bahwa hukum inklusifawalnya mengkritisi kelemahan pemikiran John Austin pada asumsi pedigree, kajian hukum linier sebagai fakta social dan pemisahan antara hukum dengan moralitas dalam pengembangan teori hukum inklusif Indonesia, disempurnakan dengan menambahkan selain moralitas,

\footnotetext{
${ }^{23}$ Susilo Andi Dharma, 'Kedudukan Pekerja/Buruh Da;Am Perkara Kepailitan Ditinjau Dari Peraturan Perundang-Undangan Dan Teori Keadilan' (2013) 2 Jurnal Supremasi Hukum.[127].

${ }^{24}$ Jawahir Thontowi, Mazhab Tamsis : Teori Hukum Inklusif (Pascasarjana Fakultas Hukum Universitas Islam Indonesia 2018).[16].
} 
juga agama menjadi sistem nilai tertinggi dalam teori hukum inklusif versi Indonesia. ${ }^{25}$ Terdapat lima asumsi dasar ${ }^{26}$ yang menjadi dukungan untuk terlahirnya teori hukum inklusif yakni:

1. Non-linier

2. Tradisi kebebasan akademik (with long tradition of Freedom)

3. Keberagaman (religiousity)

4. Sistem hukum nasional tidak otonom (non-autonomy national law)

5. Ideology keberpihakan pada kelompok masyarakat yang rentan.

\section{Kesimpulan}

Hukum inklusif hadir sebagai jawaban atas permasalahan-permasalahan yang kerap kali tidak mampu dijawab oleh undang-undang atau hukum positif. Sebagai sarana hukum untuk menyentuh wilayah yang jarang sekali memperoleh perhatian oleh para penegak hukum, hukum inklusif telah mampu untuk menjawab dan memenuhi kebutuhan keinginan masyarakat rentan untuk memperoleh keadilannya. Termasuk dalam issue yang sedang penulis angkat ini, hadirnya hukum inklusif telah mampu mengayom sekaligus sebagai cara pandang lain untuk pemenuhan atas timpangnya hak akan keadilan sebagai hak dasar kehidupan berbangsa dan bertanah air.

\section{Daftar Bacaan}

\section{Buku}

Bernard nainggolan, Perlindungan Hukum Seimbang Debitor, Kreditor Dan PihakPihak Berkepentingan Dalam Kepailitan (Alumni 2011).

Dewi Tuti Muryati DS dan EY, 'Pengaturan Tanggung Jawab Kurator Terhadap Pengurusan Dan Pemberesan Harta Pailit Dalam Kaitannya Dengan Hak Kreditor Separatis' (2017) 19 Jurnal Dinamika Sosial Budaya.

Elyta Ras Ginting, Hukum Kepailitan Teori Kepailitan (Sinar Grafika 2018).

Fred B.G. Tumbuan, "Pokok-Pokok Undang-Undang Tentang Kepailitan

\footnotetext{
25 ibid.[17].

${ }^{26}$ ibid. [17].
} 
Sebagaimana Diubah Oleh PERPU No. 1/1998” Dalam Penyelesaian UtangPiutang Melali Kepailitan Atau Penundaan Kewajiban Pembayaran Utang (Rudhy A. Lontoh ed, Alumni 2001).

Herowati Poesoko, Parate Executie Obyek Hak Tanggungan (Inkonsistensi Konfili Norma Dan Kesesatan Penalaran Dalam UUHT) (LaksBang PRESSindo 2008).

J.B. Huizink, Insoventie (Pusat Studi Hukum \& Ekonomi Fakultas hukum Universitas Indonesia 2004).

Jawahir Thontowi, Mazhab Tamsis : Teori Hukum Inklusif (Pascasarjana Fakultas Hukum Universitas Islam Indonesia 2018).

M. Faruq an-Nabahan, Sistem Ekonomi Islam : Pilihan Setelah Kegagalan Sistem Kapitalisme Dan Sosialisme, Terj. Muhadi Zainuddin (3rd edn, UII Press Yogyakarta 2002).

M. Hadi Subhan, Hukum Kepailitan: Prinsip, Norma, Dan Praktik Di Peradilan (Prenanda Media Group 2008).

Michael Murray and Jason Harris, Keay's Insolvency (Personal and Corporate Law and Principle) (Thomson Reuters (Professional) Autralian Limited 2014).

Pusat Pengkajian dan Pengembangan Ekonomi Islam (P3EI) UII, Ekonomi Islam (7th edn, Raja Grafindo Persada 2015).

Rudy Lontoh(Ed), Penyelesaian Utang Melalui Pailit Atau Penundaan Kewajiban Pembayaran Utang (Alumni 2001).

\section{Jurnal}

Sriti Hesti Astiti, 'Pertanggungjawaban Pidana Kurator Berdasarkan Prinsip Independensi Menurut Hukum Kepailitan’ (2016) 31 Yuridika.

Susilo Andi Dharma, 'Kedudukan Pekerja/Buruh Da;Am Perkara Kepailitan Ditinjau Dari Peraturan Perundang-Undangan Dan Teori Keadilan' (2013) 2 Jurnal Supremasi Hukum.

HOW TO CITE: Anis Nur Nadhiroh, 'Tanggung Jawab Kurator Terhadap Hak Pekerja' (2019) Vol. 2 No. 3 Notaire. 